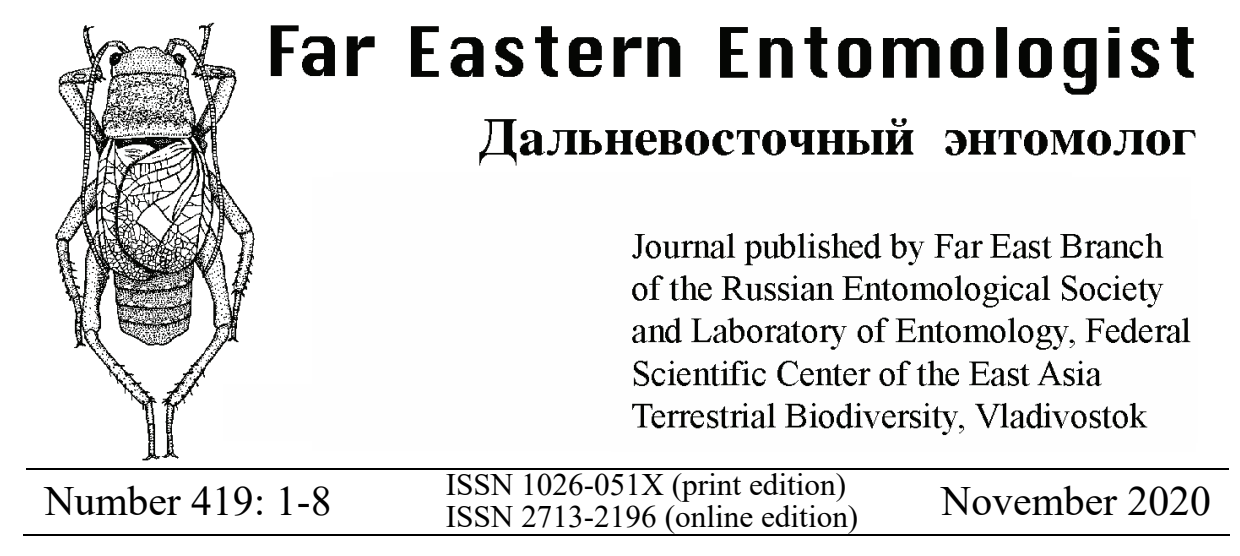

https://doi.org/10.25221/fee.419.1

http://zoobank.org/References/399AE28B-4215-4E7D-93CD-253159B5B146

\title{
TWO NEW SPECIES OF THE GENUS ERROMENUS HOLMGREN, 1857 (HYMENOPTERA: ICHNEUMONIDAE: TRYPHONINAE) FROM THE SIBERIA AND RUSSIAN FAR EAST
}

\section{R. Kasparyan}

Zoological Institute, Russian Academy of Sciences, Universitetskaya Nab. 1, St.Petersburg, 199034,Russia.E-mail: kasparyan@yandex.ru

Summary. Two new species, Erromenus atrator sp. n. (Primorskiy Territory) and E. tereshkini sp. n. (Zabaikalskiy Territory) are described in the tribe Tryphonini (Ichneumonidae). Both new species differ from other congeners by almost completely black body color and a very wide dorsal area at the base of the propodeum, formed by a fused basal area and areola, and by the distinctly raised upper edge of the antennal sockets. In the last character, in the structure of the clypeal foveae and of the ovipositor, the new species are evolutionarily close to the Holarctic species E. zonarius (Gravenhorst, 1820). A new subgroup of species zonarius in the marginatus species group is proposed. Key to black-colored species of zonarius species-subgroup of the Eastern Palaearctic and related species is given.

Key words: insects, parasitoids, Tryphonini, taxonomy, new species, Zabaikalskiy Territory, PrimorskiyTerritory, Palaearctic.

Д. Р. Каспарян. Два новых вида рода Erromenus Holmgren, 1857 (Нуmenoptera: Ichneumonidae: Tryphoninae) из Сибири и Дальнего Востока России // Дальневосточный энтомолог. 2020. N 419. С. 1-8. 
Резюме. В трибе Tryphonini (Ichneumonidae) описаны два новых восточнопалеарктических вида наездников: Erromenus atrator sp. n. (Приморский край) и E. tereshkini sp. n. (Забайкальский край). Оба новых вида отличаются от прочих видов рода почти полностью черной окраской тела и очень широкой дорсальной площадкой в основании проподеума, образованной слитыми базальным полем и ареолой. По отчетливо приподнятому верхнему краю усиковых ямок, строению клипеальных ямок и яйцеклада новые виды эволюционно близки голарктическому виду E. zonarius (Gravenhorst, 1820). Предложена новая подгруппа видов zonarius в группе видов marginatus. Дается определительная таблица черноокрашенных видов подгруппы zonarius Восточной Палеарктики и близких видов.

\section{INTRODUCTION}

Erromenus Holmgren, 1857 is moderately large Holarctic genus with about 40 species, half of them are known in Palaearctic region. The fauna of Russia comprises 14 species of Erromenus (including current data) and have been revised by author (Kasparyan, 1973; Kasparyan \& Tolkanitz, 1999; Kasparyan \& Khalaim, 2007); Nearctic species were revised by Townes \& Townes (1949) and Townes et al. (1992). The hosts of these parasitoids are sawflies of the subfamily Nematinae (Tenthredinidae) (Yu et al., 2016). Both new species closely related to E. zonarius (Gravenhorst, 1820). The aim of this paper is describe two new Eastern Palaearctic species of Erromenus and unit them with closely related E. zonarius in new subgroup zonarius, describe this subgroup and propose the key to these species and some others with black metasoma.

The holotype and paratypes of new species are deposited in the collection of Zoological Institute RAS, St Petersburg [ZIN].

\section{DESCRIPTION OF NEW SPECIES}

\section{Erromenus atrator Kasparyan, sp. $\mathbf{n}$.}

http://zoobank.org/NomenclaturalActs/29C3AB90-269D-4E13-B4C7-8A3419B20913

Figs $1-4$

MATERIAL EXAMINED. Holotype - + , Russia: Primorskiy Territory, $15 \mathrm{~km}$ NE Partizansk, nr. Frolovka, 7.VII 1996, S. Belokobylski leg. [ZIN]. Paratypes. Russia: Primorskiy Territory, Khasan District: SW of Barabash, stream Narva, 5.VIII 1978, 1 ㅇ (Kasparyan leg.); Reserve "Kedrovaya Pad", 24.VII 1982, 1 ㅇ (Kerzhner leg.) [ZIN].

DIAGNOSIS. FEMALE. Erromenus atrator sp. n. differs from other species of the genus by the completely black body, mid and hind legs (Fig. 1), and by the areola and basal area of the propodeum which merged into a large semicircular area, about 0.65 as long as wide (Fig. 3). MALE unknown. 
DESCRIPTION. FEMALE (holotype). Body length about $7.5 \mathrm{~mm}$. Fore wing $5.5 \mathrm{~mm}$, flagellum $4.5 \mathrm{~mm}$ long, with 27 flagellomeres. Temples just beyond the eyes subparallel, in posterior 0.5 roundly narrowed to occipital carina. Upper margin of antennal socket raised as a flange about 0.25 times as high as the scape is wide; frons weakly impressed near the antennal sockets. Face moderately convex, almost 2 times as wide as long, with rather coarse even punctures in median part, with fine punctures at lateral sides, and with polished impunctate small area above clypeal fovea. Clypeal foveae large, deep, but not extending to malar space, covered with very fine inconspicuous pubescence; clypeus between foveae separated from face by a strong groove. Malar space short, 0.33 times as long as the basal width of mandible. Minimal length of the temple 0.6 times as long as the transverse diameter of eye. Occipital carina at the level of lower margin of eye incurved to the hypostomal carina. Oral carina (the portion of hypostomal carina between occipital carina and mandible) slightly higher than occipital carina, and 0.5 times as long as the basal width of mandible.

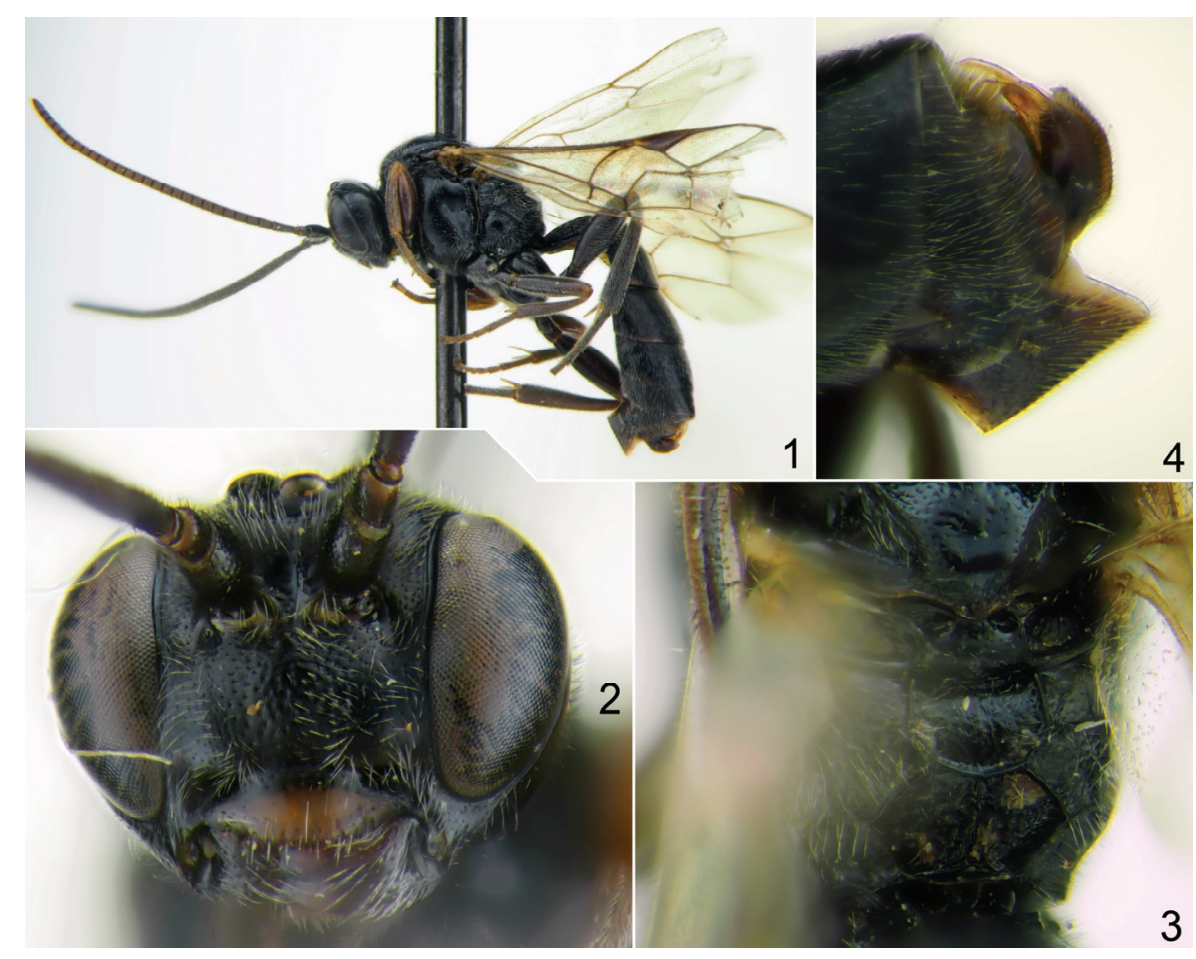

Figs 1-4. Erromenus atrator sp. n., + , holotype: 1 - habitus, lateral view; 2 - head, frontal view; 3 - propodeum, dorsal view; 4 - apex of metasoma, lateral view. 
Pronotum with strong vertical epomia; its lateral portion beyond epomia evenly coarsely punctate. Mesopleuron smooth, in lower half with rather large moderately dense punctures. Mesoscutum on median lobe with rather fine punctures separated in average by 1-2 their diameter; its lateral portion before the tegulae level and central portion before prescutellar groove covered with coarse punctures. Mesonotal flange at its posterior margin 0.5 times as wide as tegula. The lateral carina of scutellum extending about 0.6 times its length. Scutellum with large sparse punctures, almost impunctate at the apex.

Combined basal area and areola of propodeum unusually broad, 0.66 times as long as wide, smooth, semicircle (Fig. 3). Apical area of the propodeum large, hexagonal, with the strong rugosity and with obscured by rugosity one or two irregular median vertical carina.

Fore wing with an oblique areolet; nervulus strongly postfurcal and inclivous; postnervulus intercepted on lower 0.3. Nervellus in hind wing broken at its lower 0.25 . Fore tarsal claws of female densely pectinate to apex, with about 7 teeth; longest spur in middle tibia 0.75 times as long as its first tarsomere; hind femur 3.1 times as long as wide.

Terga 1 and 2 of metasoma respectively 1.15 and 0.55 times as long as wide on posterior margin; tergite 1 with distinct basolateral corners; its dorsal longitudinal carinae expand to its posterior 0.28 . Tergite 2 subpolished with weak traces of smoothened granulation, covered with moderately fine punctures, its basal corners mat and cut off by superficial oblique grooves extending about to the spiracles; gastrocoeli present at extreme base of the tergite. Terga 6 and 7 almost completely retracted under the previous tergite; their visible hind margin apically with tuft or brush of the setae (Figs 1, 4). Ovipositor sheath upcurved, wide, its setiferous part about 0.7 times as long a hypopygium; apex of ovipositor sheath emarginate with short tooth on lower corner of emargination. Ventral valve of ovipositor projecting beyond tip of dorsal valve about 0.3 times as long as length of setiferous part of sheath (in all studied specimens).

Body almost entirely black, except for lower 0.7 of dark reddish brown clypeus, fore femur, tibiae and tarsi; middle tibiae and tarsi blackish brown; spurs of middle and hind tibiae and plates in base of fore wing yellowish.

ETYMOLOGY. The name derived from the Latin atratus (black), refers to the black color of a new species.

Erromenus tereshkini Kasparyan, sp. n.

http://zoobank.org/NomenclaturalActs/5FC7041B-977F-4D65-B196-611AAA2CB97D

Figs 5-8

MATERIAL EXAMINED. Holotype - $q$, Russia: Zabaikalskiy Territory, "Chita Province, Bylyra W of Kyra, steppe slopes and grove, 20.VI 1975, Kasparyan” [“Читинская обл., Былыра W пос. Кыра, степные склоны и колки, 20.VI 1975, Каспарян” (about 300 km SW of Chita)] [ZIN]. 
DIAGNOSIS. FEMALE. Erromenus tereshkini sp. n. differs from other species with a black body of the zonarius subgroup by rufous apical metasomal segments 6-8 and by rufous fore and mid legs beyond their trochanters; its oral carina raised in a distinct short lobe. It also differs from closely related $E$. atrator $\mathrm{sp}$. n. but differs in having the basal area and areola longer, and the areola narrowed posteriorly (Fig. 7). In the last character the new species closer to E. zonarius (Gravenhorst), but differs in form of oral carina, colouration of metasoma and in less high upper margin of antennal socket. MALE unknown.

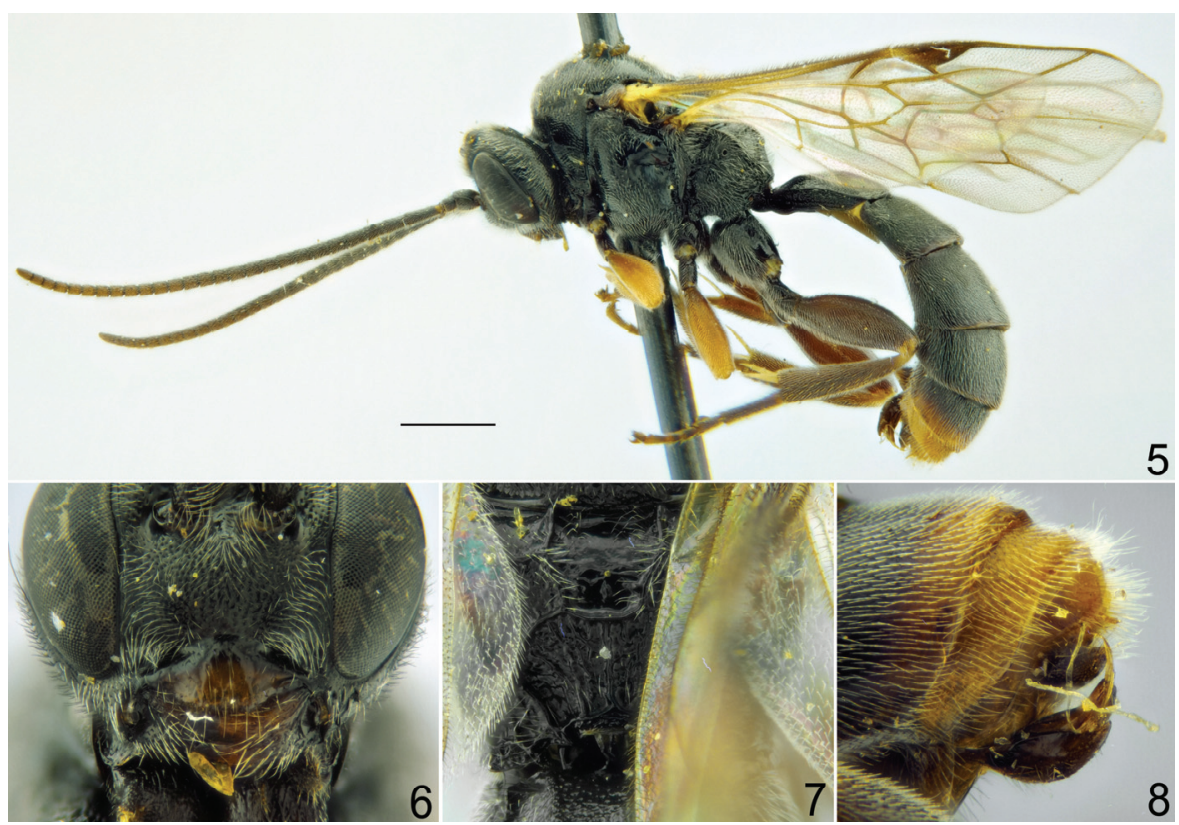

Figs. 5-8. Erromenus tereshkini sp. n., 9 , holotype: 5 - habitus, lateral view; 6 - head, frontal view; 7 - propodeum, dorsal view; 8 - apex of metasoma, lateral view.

DESCRIPTION. FEMALE (holotype). Body length about $7.5 \mathrm{~mm}$. Fore wing $5.8 \mathrm{~mm}$, flagellum $4.6 \mathrm{~mm}$ long, 26 flagellomeres. Temples just beyond the eyes slightly convex, in posterior 0.5 roundly narrowed to occipital carina. Upper margin of antennal socket raised as a flange about 0.3 times as high as the scape is wide; frons in the lower half impressed above the antennal sockets. Face moderately convex, 2.1 times as wide as long, with rather coarse dense punctures centrally, with fine punctures at lateral sides. Clypeus polished with small sparse punctures at basal 0.33 (up to transversal convexity), its lower edge in median 0.4 obtuse with some short and weak vertical rugae. Clypeal foveae large, deep with fine pubescence, impressed laterally to malar space; clypeus between foveae separated from face by a strong groove. Malar space short, 0.3 times as long as the basal width of mandible. 
Minimal length of the temple 0.5 times as long as the transverse diameter of eye. Occipital carina sharp to the hypostomal carina. Oral carina raised in moderately high short lobe, 2 times as long as high, and 0.4 times as long as the basal width of mandible.

Pronotum with strong vertical epomia; its lateral portion beyond epomia evenly coarsely punctate. Mesopleuron smooth, in lower half and along anterior margin with rather large moderately dense punctures; its upper corner before subtegular ridge scabrous with rugosity. Mesoscutum on median lobe with rather fine punctures separated in average by 1-2 their diameter; its hind half to prescutellar groove covered with coarse and dense punctures. Mesonotal flange at its posterior margin 0.4 times as wide as tegula. The lateral carina of scutellum extending about 0.5 its length. Scutellum with moderately large sparse punctures, at extreme apex densely punctate.

Propodeum with weak shallow punctures only on first and partly on second lateral areas; merged basal area and areola smooth, 1.0 times as long as maximum width at costulae (Fig. 7). Apical area of the propodeum large, hexagonal, with the strong rugosity and with obscured by rugosity an irregular median vertical carina. The pleural areas and all three apical areas coarsely rugose.

Fore wing with an oblique areolet; nervulus strongly postfurcal and inclivous; postnervulus intercepted on lower 0.33 . Nervellus in hind wing broken at its lower 0.25 . Fore tarsal claws of female densely pectinate to apex, with about 6 teeth; longest spur in middle tibia 0.85 times as long as its first tarsomere; hind femur 2.7 times as long as wide.

Metasomal terga 1 and 2 respectively 1.0 and 0.55 times as long as wide on posterior margin; tergite 1 with distinctly projecting basolateral corners; its dorsal longitudinal carinae expand to its posterior 0.2 . Tergite 2 subpolished, partly with weak traces of smoothened granulation, covered with moderately size rather dense punctures separated in average by 1-2 their diameter; anterior corners of tergite 2 mat, scabrous and cut off by superficial grooves extending from basal third of anterior margin of tergite about to the spiracles; gastrocoeli present at extreme base of the tergite. Tergites 6 and 7 retracted under the previous tergite; their visible hind margin apically with tuft or brush of the setae (Fig. 8). Ovipositor sheath upcurved, wide, its setiferous part about 0.7 as long a hypopygium; apex of ovipositor sheath almost pointed, its tip with small emargination. Ventral valve of ovipositor projecting beyond tip of dorsal valve about 0.3 times as long as length of setiferous part of sheath.

Body almost entirely black, except for lower 0.7 of clypeus, fore and middle femur and tibiae and tarsi which are rufous yellow; hind femur, tibia and tarsus brownish black, femur partly with reddish brown tinge, tibia with small basal yellow spot, tibial spurs whitish yellow; apical half of tergite 5 and metasomal segments $6-$ 8 entirely rufous (Fig. 5, 8).

ETYMOLOGY. The species is named in the memory of my friend, Belarusian ichneumonologist Aleksandr Mikhailovich Tereshkin (1953-2020). 


\section{DISCUSSION}

Both new species are closely related to the Holarctic species Erromenus zonarius (Gravenhorst, 1820) and belong to marginatus species group. The species of this group are united by the following features. Areolet present. Clypeal foveae large. Front tarsal claw of female pectinate almost to apex, of male weakly pectinate at base. Tergite 2 with a pair of shallow oblique basolateral grooves. Tergite 7 of female with median apical brush or tuft of long setae. Ovipositor sheath broad, beyond apical 0.3 gradually tapered to apex which usually with a shallow oblique emargination (concavity).

The marginatus species group includes two Holarctic (zonarius Gravenhost, 1820 and punctulatus Holmgren, 1857), three Nearctic and five Palaearctic species (junior Thunberg, 1822, brunnicans Gravenhorst, 1829, alpinator Aubert, 1969, and two new species - atratus sp. n., tereshkini sp. n.). In this group, the author (Kasparyan, 1973) considered two Palaearctic species - analis Brischke, 1871 and bibulus Kasparyan, 1973, which later have been united with several Nearctic species respectively into the analis and caelator species groups (Townes et al., 1992).

The two new species and E. zonarius are evolutionarily close and can be distinguished into a new separate subgroup zonarius. They are united by the characters given in key below.

\section{Key to East Palaearctic black-colored species of Erromenus marginatus group}

1. Upper edge of antennal sockets strongly projecting as a flange (0.25-0.5 times as high as the scape is wide). Terga 2 and 3 polished with distinct punctures. Clypeal foveae large, laterally touching or almost touching to compound eye. Antenna usually with 26-31 flagellomeres. Subgroup zonarius

- Upper edge of antennal sockets not raised or hardly projecting (0.1 times as high as the scape is wide). Terga 2 and 3 mat, scabrous (with irregular rugosity) and with indistinct punctures. Clypeal foveae moderately large, laterally separated from the eye by about the length of the cheek (malar space). Antenna with 20-26 flagellomeres. Legs, except black coxae and trochanters, usually reddish ................................... E. punctulatus Holmgren

2. Areola beyond the costulae semicircular and rather short, about 0.33 times as long as wide (Fig. 3). Hind tibia completely blackish, without small basal yellow spot; middle and hind legs completely black (Fig. 1). Clypeal foveae large, deep, but not extending to malar space. Oral carina slightly higher than occipital carina, 0.5 times as long as basal width of mandible

E. atrator sp. n.

- Areola beyond the costulae 0.5-0.6 times as long as wide with its lateral sides directly narrowed to the apical area (Fig. 7). Hind tibia yellowish rufous or brownish black and always with a basal yellow spot; middle legs beyond trochanters yellowish rufous (Fig. 5) or occasionally completely black. Clypeal foveae large, deep, extending laterally to malar space

3. Oral carina projecting as moderately high lobe, 2 times as long as high, and 0.4 times as long as the basal width of mandible. Upper margin of antennal socket raised as a flange about 0.3 times as high as scape width. Metasoma black with apical half of tergite 5 and terga 6-8 entirely rufous (Figs 5,8 ). Tegulae blackish brown. In holotype antenna with 26 flagellomeres; fore wing $5.9 \mathrm{~mm}$. 
- Oral carina slightly higher than occipital carina, 0.5 times as long as basal width of mandible. Upper margin of antennal socket raised as a flange about $0.35-0.50$ times as high as scape width. Tegulae blackish with antero-lateral margin usually whitish. Antenna with 26-31 flagellomeres; fore wing $4.2-6.5 \mathrm{~mm}$

E. zonarius Gravenhors

\section{ACKNOWLEDGMENTS}

I am cordially grateful to Julia Astafurova and Andrey Khalaim (ZIN) for kind help in the preparation of photos. The work was supported by the Russian Foundation for Basic Research (grant no 19-04-00027) and performed in the framework of the Russian State Research Project No. AAAA-A19-119020690101-6.

\section{REFERENCES}

Kasparyan, D.R. 1973. Ichneumonidae (Subfamily Tryphoninae) Tribe Tryphonini. Nauka, Leningrad. 320 pp. (Fauna of the USSR. Hymenoptera Vol. III. Number 1). [In Russian, English translation: Amerind Publishing Co. Ltd., New Delhi, 1981. 414 pp.]

Kasparyan, D.R. \& Tolkanitz, V.I. 1999. Ichneumonidae subfamily Tryphoninae: tribes Sphinctini, Phytodietini, Oedemopsini, Tryphonini (Addendum), Idiogrammatini. Subfamilies Eucerotinae, Adelognathinae (addendum), Townesioninae. Nauka, St. Petersburg, 404 pp. (Fauna of Russia and Neighbouring Countries. Insecta Hymenoptera. Vol. III. Number 3). [In Russian]

Kasparyan, D.R. \& Khalaim, A.I. 2007. Subfamily Tryphoninae. P. 333-404. In: Lelej, A.S. (Ed.), Key to the insects of Russian Far East. Vol. IV. Neuropteroidea, Mecoptera, Hymenoptera. Pt 5. Dalnauka, Vladivostok, 1052 pp. [In Russian]

Townes, H.K. \& Townes, M. 1949. A revision of the genera and of the American species of Tryphoninae Part I. Annals of the Entomological Society of America. 42: 321-395.

Townes, H.K., Gupta, V.K. \& Townes, M. 1992. The Ichneumon-flies of America north of Mexico Part 11. Tribes Oedemopsini, Tryphonini and Idiogrammatini (Hymenoptera: Ichneumonidae: Tryphoninae). Memoirs of the American Entomological Institute, 50: 1296.

Yu, D.S.K., van Achterberg, C. \& Horstmann, K. 2016. Taxapad 2016, Ichneumonoidea 2015. Nepean, Ontario, Canada. Database on flash-drive (CD). Available at: www.taxapad.com 